\title{
PENERAPAN BIAYA STANDART SEBAGAI ALAT \\ PENGENDALIAN BIAYA PERUSAHAAN
}

*(Nurul Badriyah

Fakultas Ekonomi

Universitas islam Lamongan

\begin{abstract}
ABSTRAK
penelitian (Descriptive Research) adalah penelitian yang menggambarkan realita obyek penelitian dengan apa adanya dengan menjabarkan secara mendetail apa yang diamati dilapangan tanpa mengadakan manipulasi atau realitas yang dibiarkan apaa danya, dalam penelitian ini menghimpun konsep dan menghimpun fakta realitas yang ada.dengan rumusan masalah Bagaimana cara melaksanakan anggaran peroduksi sebagai dasar penghitungan biaya pemakaian bahan baku. Bagaimana perhitungan biaya pemakaian bahan baku sedemikian rupa sehingga biaya-biaya yang berhubungan dengan bahan baku dapat ditekan seminimal mungkin.
\end{abstract}

Kata kunci : biaya standar dan pengendalian biaya bahan baku 


\section{PENDAHULUAN}

Dalam mengahadapi persaingan yang semakin ketat dalam dunia usaha saat ini, banyak cara yang dilakukan dan dikembangkan untuk mencapai tujuan secara efektif dan efisien, sehingga perlu adanya pemikiran-pemikiran dan pengkajian-pengkajian untuk mendapatkan cara yang lebih baik guna menghasilkan outputsecara baik dan dapat mencapai sasaran secara tepat waktu, tepat jumlah, dan berkualitas dengan biaya yang seminimal mungkin.

Hampir semua perusahaan dalam kegiatan proses produksinya tidak lepas dari masalah biaya, khususnya adalah perhitungan biaya pemakaian bahan baku, perhitungan biaya pemakaian bahan baku merupakan unsur yang sangat penting bagi suatu perusahaan brkaitan dengan biaya penyimpanan ( holding costs ). Biaya pemesanan, baiaya produksi, dan biaya cadangan bahan ( shortage costs ). Selain tu juga perhitungan biaya pemakaian bahan baku dapat menimbulkan beberapa masalah penting yang sering rumit, dan kadang-kadang sangat kotroversial dalam kaitannya dengan perhitungan biaya pemakaian bahan baku yang digunakan dalam proses produksi dan persediaan yang akan digunakan dalam periode mendatang.

Demi menjamin kelancaran proses produksi serta menjaga kelangsungan hidup perusahaan maka perusahaan harus membuat alternatif cara pengadaan perhitungan biaya pemakaian bahan baku yaitu dengan membuat anggaaran produksi, agar anggaran produksi berfungsi dengan baik, maka estimasi yang memuat didalamnya harus cukup akurat, sehingga tidak jauh berbeda dengan realisasinya, untuk itu diperlukan data informasi dan pengalaman yang merupakan faktor-faktor yang harus dipertimbangkan dalam anggaran produksi.

Anggaran produksi dibuat untuk menunjang biaya pemakaian bahan baku dan mengatur tingakat produksi sedemikian rupa sehingga perhitungan baiaya pemakaian bahan baku dapat lebih efektif dan efisien, oleh karena itu diperlukan anggaran produksi yang tepat, apabila dalam anggaran produksi tidak diikuti dengan perhitunganbiaya pemakaian bahan baku, maka akan mengakibatkan biaya yang dikeluarkan tidak sesuai yang dibutuhkan. Biaya dalam arti luas adalah pengorbanan ekonomi yang diukur dalam satuan uang yang telah terjadi atau kemungkinan akan terjadi untuk tujuan tertentu. Mulyadi (2002:8). Sedangkan Henry Simamora (2002:39) mengemukakan, Biaya sebagai pengorbanan yang dilakukan untuk mendapatkan barang atau jasa

Jadi dapat disimpulkan dari dua definisi diatas, biaya adalah pengorbanan ekonomi yang diukur dalam satuan uang yang telah terjadi atau mungkin akan terjadi yang dilakukan untuk mendapatkan barang atau jasa. Penggolongan Biaya Tujuan akhir akuntansi biaya adalah menyediakan informasi tentang biaya untuk manajemen guna membantu mereka dalam mengelola perusahaan atau departemennya. Dalam mengelola perusahaan manajemen membutuhkan biaya yang akurat.

Dalam akuntansi biaya, biaya digolongkan dengan berbagai macam cara. Umumnya penggolongan biaya ini ditentukan atas dasar tujuan yang hendak dicapai dengan penggolongan tersebut, karena dalam akuntansi biaya dikenal dengan konsep "different costs for different purpose", biaya yang berbeda untuk tujuan yang berbeda, (Mulyadi:2009:13).

\section{METODE PENELITIAN}

Ditinjau dari rancang bangun penelitianya, maka penelitian pada hakekatnya adalah penelitian deskriptif.Menurut Syafudin Zuhri (2001:8-11), menyatakan bahwa :"penelitian (Descriptive Research) adalah penelitian yang menggambarkan realita 
obyek penelitian dengan apa adanya dengan menjabarkan secara mendetail apa yang diamati dilapangan tanpa mengadakan manipulasi atau realitas yang dibiarkan apaa danya, dalam penelitian ini menghimpun konsep dan menghimpun fakta realitas yang ada.

Tahapanalisis data merupakan suatu langkah yang sangat penting dalam penelitian. Sebagaimana yang dikemukakan oleh P. Joko Subagyo, pada dasarnya analisis data adalah kegiatan untuk merumuskan data sehingga dapat diperoleh suatu kebenaran atau ketidak benaran dari suatu hipotesa, dalam analisis diperlukan suatu imajinasi dan kreativitas sehingga di uji kemampuan peneliti dalam menalar sesuatu ( Mulyadi 2000:104).

Harga pokok biaya produksi menurut metode full costing terdiri dari

1.Biaya bahan baku

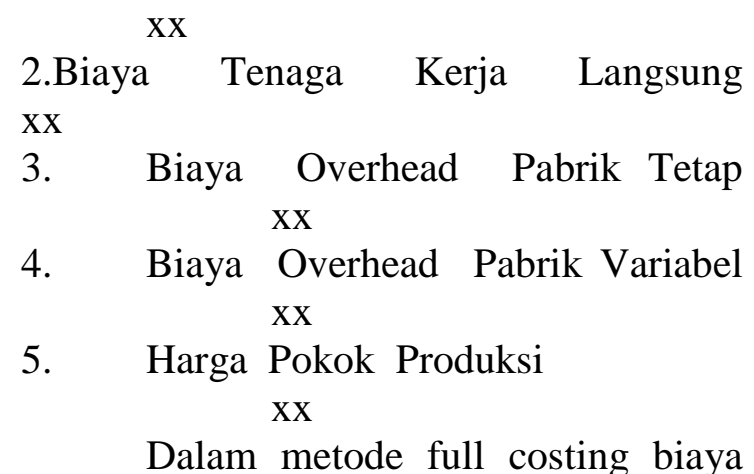
overhead pabrik baik yang yang berprilaku tetap maupun fariabel,dibebankan kepada produk yang diproduksi atas dasar tarif yang ditentukan dimuka pada kapasitas normal atau atas dasar biaya overhead pabrik sesungguhya,oleh karna itu biaya overhead tetap akan melekat pada harga pokok persediaan produk dalam proses dan persediaan produk jadi yang belum laku dijual dan dianggap sebagai biaya ( angsur harga pokok penjualan) apabila produk jadi tersebut telah dijual.

Teknik Analisis yang di gunakan dalam penelitian ini adalah full costing Full costing dinyatakan sebagai berikut Hargajual $=$ By.Produksi + By. Non Produksi + Laba yang diharapkan

Dengan pendekatan Full Costing, harga jual dihitung dengan rumus :
By.Non Produksi + Laba yang diharapkan

Mark Up =

By.Produksi

By.NonProduksi + ( Y\% X aktivapenuh )

Mark Up =

By.Produksi

Hargajual $=$ By.Produksi + Mark Up

\section{HASIL PENELITIAN}

Dari hasil pengolahan data dapat di ketahui pada UD.Sumberagung Lamongan dapat menentukan harga jual dengan metode full costing, itu terbukti dari perhitungan pada tahun 2011 yang diketahui sebesar $6.500 \mathrm{~kg}$ untuk kemasan $25 \mathrm{Kg}$ dan $4.200 \mathrm{Kg}$ untuk kemasan 50 $\mathrm{Kg}$, pada tahun 2012 sebesar 6.150 kemasan $25 \mathrm{Kg}$ dan 4.400 untuk $50 \mathrm{Kg}$. Dalam penjualan perusahaan UD.Sumberagung Lamongan untuk beras $25 \mathrm{~kg}$ kualitas satu tahun 2011 adalah $82.827 \mathrm{~kg}$,total penjualanya sebesar $\mathrm{Rp}$ 488.680.000 sedangkan pada tahun 2012 adalah $96.400 \mathrm{~kg}$ total penjualanya sebesar Rp 588.404.000

Penjualan dengan katagori dua yaitu beras $50 \mathrm{~kg}$ kualitas dua pada tahun 2011 $263.095 \mathrm{~kg}$ total penjualanya sebesar 1.104.999.000 sedangkan pada tahun2012 $230.673 \mathrm{~kg}$ total penjualanya sebesar Rp1.014.961.200

Dalam menentukan penjualan pasti ada kemungkinan untung dan rugi dalam perusahaan UD.Sumberagung Lamongan setelah kami hitung dengan pendekatan metode full costing dengan laba yang diharapkan menetapkan harga jual pada tahun 2011 beras $25 \mathrm{~kg}$ kualitas satu menghasilkan laba Rp 25.127.500.00 dan pada tahun 2012 menghasilkan laba Rp 27.236 .500 , sedangkan beras yang $50 \mathrm{~kg}$ kualitas dua tahun 2011 menghasilkan laba sebesar Rp 31.510.550.00 dan pada tahun berikutnya mengalami kenaikan sebesar 44.076.200.000. 


\section{PEMBAHASAN}

Biaya standart yang ditetapkan oleh UD. Sumberagung Lamongan sudah sesuai, Pengendalian biaya oleh UD. Sumberagung Lamongan sudah sangat baik.Peranan biaya standart yang digunakan oleh UD. Sumberagung Lamongan dalam mengendalikan biaya sudah sangat tepat.

\section{SIMPULAN DAN SARAN}

\section{Simpulan}

Dari hasil pengolahan data dapat di ketahui pada UD. Sumber agung Lamongan dapat menentukan biaya standart dengan metode full costing, itu terbukti dari perhitungan pada tahun 2012 yang diketahui sebesar $6.500 \mathrm{~kg}$ untuk kemasan $25 \mathrm{Kg}$ dan $4.200 \mathrm{Kg}$ untuk kemasan $50 \mathrm{Kg}$, pada tahun 2013 sebesar 6.150 kemasan $25 \mathrm{Kg}$ dan 4.400 untuk 50 $\mathrm{Kg}$.

Dalam mengendalikan biaya UD. Sumber agung Lamongan untuk beras 25 kg kualitas satu tahun 2012 adalah 82.827 $\mathrm{kg}$,total penjualanya sebesar Rp 488.680.000 sedangkan pada tahun 2013 adalah $96.400 \mathrm{~kg}$ total penjualanya sebesar Rp 588.404.000

Penjualan dengan katagori dua yaitu beras $50 \mathrm{~kg}$ kualitas dua pada tahun $2012263.095 \mathrm{~kg}$ total penjualanya sebesar 1.104.999.000 sedangkan pada tahun 2013 $230.673 \mathrm{~kg}$ total penjualanya sebesar Rp1.014.961.200.

Peranan biaya standart yang digunakan untuk mengendalikan biaya UD. Sumber agung Lamongan setelah kami hitung dengan pendekatan metode full costing dengan laba yang diharapkan menetapkan harga jual pada tahun 2012 beras $25 \mathrm{~kg}$ kualitas satu menghasilkan laba Rp 25.127.500.00 dan pada tahun 2013 menghasilkan laba Rp 27.236.500 sedangkan beras yang $50 \mathrm{~kg}$ kualitas dua tahun 2011 menghasilkan laba sebesar Rp
31.510.550.00 dan pada tahun berikutnya mengalami kenaikan sebesar 44.076.200.000.

\section{Saran}

Setelah dilakukan penelitian dan menghasilkan suatu kesimpulan, maka peneliti mencoba untuk memberikan saran yang kiranya bermanfaat:

Dalam menentukan penjualan pasti ada kemungkinan untung dan rugi dalam perusahaan UD. Sumber agung Lamongan sebaiknya di hitung dengan pendekatan metode full costing untuk menentukan penjualan dan biaya - biayayang dikeluarkan oleh perusahan,

Hasil penelitian ini dapat dijadikan sebagai bahan pembanding antara teori dengan praktek yang akan dihadapi dalam memcahkan masalah yang terjadi pada perusahaan.

Hasil penelitian ini dapa melengkapi karya ilmiah mahasiswa Universitas Islam Lamongan dan dapat digunakan sebagai pembanding bagi mahasiswa lain untuk penelitian dimasa yang akan datang.

\section{DAFTAR PUSTAKA}

Arikunto, Suharsimi. (2010). Prosedur Penelitisan - Suatu Pendekatan Praktek. Jakarta: Rineka Cipta.

Baridwan, Zaki. (20088). Intermediate Accounting. Yogyakarta: BPFE.

Choiri, Anis dan Imam Ghozali. (2007). Teori Akuntansi. Semarang: BP Undip.

Dajan, Anto. (2005). Pengantar Metode Statistik. Jakarta: PT. Pustaka LP3ES.

Garisson, Roy H diterjemahkan Bambang Purnomosidi dan Erwan Dukat. (1997). Akuntansi Managemen (Managerial Acounting). Texas: Business Publication. Inc. Lpano.

Halim, Abdul. (20066). Dasar-Dasar Akuntansi Biaya. Yogyakarta: BPFE.

Harahap, Sofyan Safri. (2006). Teori Akuntansi. Jakarta: PT. Raja Grafindo Persada. 
Harnanto. (2003). Akuntansi Biaya Perhitungan Harga Pokok Produk Sistem Biaya Historis. Yogyakarta: BPFE.

Kholik, Zaenal. (2000). Pengantar Managemen Pemasaran. Surabaya: Purna Cipta.

Machfoed, Mas'ud. (2012). Akuntansi Managemen. Yogyakarta: BPFE.

Mulyadi. (2007). Akuntansi Managemen Konsep, Manfaat dan Rekayasa. Yogyakarta: STIE YKPN UGM.

Mulyadi. (2006) Akuntansi Biaya. Yogyakarta: STIE YKPN UGM.

Mulyadi. (1983). Akuntansi Biaya Penentuan Harga Pokok dan Pengendalian Biaya. Yogyakarta: BPFE.

Subagjo, P. Joko (1997). Metode Penelitian Dalam Teori dan Praktek. Jakarta: Rineka Cipta.

Sudjana (1996). Metode Statistika. Bandung: Tarsito.

Sulastiningsih dan Zulkifli. (1999). Akuntansi Biaya Dilengkapi dengan Isu-Isu Kontemporer. Yogyakarta: UPP AMP YKPN.

Supriyono, R. A. (2000). Akuntansi Biaya dan Penentuan Harga Pokok. Yogyakarta: BPFE.

Sugiyono,D.R. (2010). Statistiki Untuk Penelitian. Bandung: Alfa Beta.

Swasta, Basu. (2006). Asas-Asas Marketing. Yogyakarta: Liberty.

The Liang Gie (2006). Administrasi Perkantoran Modern. Yogyakarta: Nur Cahya.

Tim Penyusun Pedoman Penulisan skripsi. (2015). Pedoman Penulisan Skripsi. Lamongan: Unisla.

Usry, Matz. (2002). Akuntansi Biaya dan Harga Pokok - Perencanaan dan Pengendalian. Bandung: AAB.

Zuhri, Saifudin (2011). Metodologi Penelitian - Pendekatan Teoritas Aplikatif 
